\title{
Yapısal İşlevselci Teori ve Toplumsal Tabakalaşma
}

\author{
Kemal AYDIN*
}

\section{Özet}

$\mathrm{Bu}$ çalışmada yapısal işlevselcilerin tabakalaşama ve eşitsizlik konusuna yaklaşımları incelenmektedir. Makalenin ilk bölümünde işlevselci ekölün öncülerine kısaca değinilmektedir. İkinci bölümde Durkheim'in tabakalaşmaya bakış açısı iş bölümü, anomik ve baskıcı iş bölümü, devletin tabakalaşmadaki rolü ve meslek birlikleri çerçevesinde çözümlenerek, tabakalaşma açısından Durkheim, Marx ve Weber ile mukayese edilmektedir. Üçüncü bölümde 1950’li yıllardan sonra sosyoloji alanında geliştirilen modern yapısal işlevselciliğin tabakalaşma teorileri Parsons ve Davis Moore örneğinden hareketle özetlenmekte ve son bölümde çatışma, uyum, güç/iktidar ve sosyal eşitsizlik kavramlarının yapısal işlevselci tabakalaşma ekolünde hangi bağlamlarda tartışıldığ i irdelenmektedir.

Anahtar kelimeler: Toplumsal tabakalaşma, yapısal işlevselcilik, Durkheim, Parsons, Davis ve Moore

\section{Structural Functionalism and Social Stratification}

\section{Abstract}

This study analyzes the foundation of structural functionalists' perspectives in social stratification and inequality. The first part of this article briefly mentions the pioneers of functionalist school. In the second part, Durkheim' views on stratification is discussed within the context of division of labor, role of state and occupational groupings. The third section focuses on modern structural functionalist approach to social stratification by analyzing Parsons, Davis and Moore theories. In the last section, modern structural functionalists' perspectives on the concepts of power, authority, conflict and consensus are discussed.

Key words: Structural functionalism, social stratification, Durkheim, Parsons, Davis and Moore

\section{Yapısal İșlevselci Teori ve Toplumsal Tabakalaşma}

\section{Giriş}

Sosyolojinin önemli bir alt dalı olan toplumsal tabakalaşma ya da sosyal eşitsizliğin kökeni, nedenleri, değişik tarihi dönemlerde aldığı formlar ve top-

* Kocaeli Üniversitesi, kemal.aydin111@gmail.com 


\section{4 • YALOVA SOSYAL BİLİMLER DERGİSİ}

lum üzerindeki sonuçları sosyologları meşgul etmeye devam etmektedir. Günümüzün çağdaş sosyolojik yaklaşımlarında birbirine zıt diyebileceğimiz bir hayli tabakalaşma ve sosyal eşitsizlik teorileri ve bu teorilere dayalı nitel ve nicel saha araştırmaları bulunmaktadır. Tabakalaşma literatüründe farklı yaklaşımlar çok genel olarak klasik Marx, Weber ve işlevselcilik olmak üzere üç kategoride sinıflandırılabilir.

Bu makalede yapısal işlevselci ekolün toplamsal tabakalaşma/sosyal eşitsizlik sorununa bakış açıları incelenmektedir. Diğer tabakalaşma teorilerinde tek bir yaklaşım olmasına rağmen işlevselcilik okulunda çok farklı araştırmac1lar olduğu için tek bir yapısal işlevselci tabakalaşma teorisinin olduğunu söylemek güçtür. Bu makalede ilk önce yapısal işlevselci okulun öncüleri olan Comte, Spencer ve Durkheim'a değinilmektedir.

İkinci bölümde ise işlevselciliğin en önemli temsilcisi olan Durkheim'ın tabakalaşmaya bakış açısı ünlü çalışması Toplumsal İ̧̧ Bölümü’nden hareketle konumlandırılmakta, anomik ve baskıcı işbölümünün sosyal eşitsizliğe nasıl neden olduğu tartış1lmaktadır. Sosyal eşitsizliğin normal seyrinde devam etmesi için Durkheim çözüm önerisi olarak devletin rolü ve meslek birlikleri ile ilgili temel görüşleri kısaca özetlenerek Durkheim, Marx ve Weber ile tabakalaşma açısından kısaca mukayese edilmektedir.

Üç, dört ve beşinci bölümlerde Durkheim'dan sonra 1950'li yıllarda Amerika'da geliştirilen modern yapısal işlevselciliğin temel kavramları ele alınarak Parsons'un tabakalaşma analizleri gözden geçirilmektedir. İşlevselci tabakalaşma teorisi dendiğinde hiç şüphesiz ilk akla gelen Davis ve Moor'un işlevselci tabakalaşma teorisidir. Bu teori yayınlandığı yıllarda büyük tartışmalara yol açmış işlevselci ekol içinde en güçlü tabakalaşma teorisi olarak bilinmektedir. Beşinci bölümde Davis ve Moore'un tabakalaşmanın ilkeleri ile ilgili öne sürdükleri temel önerme ve hipotezleri çözümlenmekte ve bu teoriye yapılan eleştiriler ele alınmaktadır.

Altıncı ve son bölümde ise güç/iktidar, devlet, çatışma ve uyum gibi tabakalaşma literatüründe önemli bir yer işgal eden bu kavramların işlevselci tabakalaşma ekolünde hangi bağlamlarda tartışıldığ irdelenmektedir.

\section{Yapısal İşlevselci Teori ve Öncüleri}

Yapısal işlevselcilik sosyal bilimlerde özellikle de sosyoloji ve antropolojide en önemli teorik yaklaşımlardan biridir. Bir toplum canlı bir organizma olarak varlığını nasıl sürdürür sorusu sorulduğunda bu soruya en kapsamlı yanıt yapısal-işlevselci (fonksiyonalizm) ekolden gelmektedir.

Modern işlevselciliğin en önemli öncüleri Comte, Spencer, Pareto ve Durkheim'dir. 
"İşlevselcilik Durkheim tarafından sistemleştirilmiş ve daha sonra ise Parsons ve Merton tarafindan geliştirilmiştir. Comte, Spencer ve Pareto toplumsal sistemin kısımları arasındaki karşılıklı bağımlılık kavramı üzerinde, Durkheim ise bütünleşme ve dayanışma üzerinde durmuştur" (Wallace ve Wolf 2012, s. 44).

Sosyolojinin kurucusu olarak kabul edilen Comte sosyolojiyi sosyal statik ve sosyal dinamik olmak üzere ikiye ayırmıştır. Comte aynı zamanda pozitivist bilim anlayışının da en önemli temsilcilerinden biridir. Comte toplumsal dengenin temelleri ile ilgili incelemesinde 'sosyal statik' (düzen) ve 'sosyal dinamik' (değişme, ilerleme) ile ilgilenmiştir. Sosyal statik her toplumdaki göreli istikrarlı ilişkiler ile sosyal yapı üzerine odaklanır. Sosyal dinamik ise insanlığın bir aşamadan diğerine geçmesini, yani toplumdaki değişimi ifade eder. Sosyal statik insani ve sosyal varlığın kanunlarını bulmaya çalışırken sosyal dinamik sosyal değişmenin kanunları ile ilgilidir (Kösemihal 1968, Ritzer 2008).

Comte sosyal statik incelemesinde toplumsal sistemin parçaları arasında karşılıklı bağımlılık bulunduğunu ifade ederek bütün ile parçalar arasında uyumsuzluğun 'patolojik' olduğunu ileri sürmüş ve buradan da işlevsel denge kavramına ulaşmıştır. Comte denge kavramını biyolojik organizma ve homoestatsis yaklaşımından almıştır. Bir örnek ile açıklarsak düşüp dizinizi yaraladığınızda vücut süratle kendini korumaya alarak kabuk bağlayacak ve vücut dengeye kavuşacaktır (Wallace ve Wolf 2012, s. 44). Comt'a göre toplum da aynen bu şekilde organizma benzeri bir hal ile devam etmektedir. İşlevselciler, toplum ile büyük bir vücudun işlevini yerine getirebilmesi için birlikte çalışan parçalar(organlar) veya sistemlerden oluşan canlı bir organizma arasında kıyaslama, benzetme yapılabileceğini öne sürerler (Swingewood, 1998).

"Spencer'in (1820-1903) ismi farklılaşma kavramı dolayısı ile yapısal işlevselciliğin önderlerinden biri olarak kabul edilmektedir. Spencer'in farklılaşmadan sistemin farklı kısımları arasında toplumların büyümesi dolayısı ile kaçınılmaz olarak ortaya çıkan karşılıklı bağımlılık halini kast etmiştir. Spencer'in evrimci yaklaşımı Durkheim'in daha sonraları Toplumda İşbölümü'nde ifade edilmiş olan açıklamalarına genel olarak benzemektedir" (Wallace ve Wolf, s. 45).

\section{Emile Durkheim, Tabakalașma ve Sosyal Eșitsizlik}

Emil Durkheim (1858-1917) çağdaş işlevselciliğin en önemli önderidir. "Durkheim toplumsal evrimi kabile topluluklarının mekanik dayanışmasından, sanayi toplumlarının özelliği olan organik dayanışmaya doğru bir hareket olarak gördü. İlkel toplumların özelliğinin güçlü bir ortak vicdan (collective 


\section{6 • YALOVA SOSYAL BİLIMLER DERGİSİ}

conscience) olduğunu kanıtlamaya çalıştı ve bunu, "aynı toplumun ortalama vatandaşlarında ortak olan inanç ve duyguların tümü” olarak tanımladı. İşbölümü arttıkça bireycilik de arttı. Bir sonuç olarak, ortak vicdanda karşılıklı bir azalma ve insanları bir arda tutan kendine yeterliğin eksikliği ve rollerin birbirine karşılıklı bağımlılı̆̆ ile nitelenen organik dayanışmaya doğru bir değişim oldu" (Wallace ve Wolf, s. 46).

Marx ve Weber'in toplumsal tabakalaşma ve sosyal eşitsizlikle ilgili teorileri varken Durkheim'in toplumsal tabakalaşma ile ilgili bir teorisinin olmadığ1 düşünülebilir. Durkheim'in topluma bakış açısı Weber ve Marx'a göre daha pozitif gibi görülebilir çünkü organik dayanışmanın ve mesleki uzmanlaşmanın geçerli olduğu modern toplumlarda insanlar yasal ve ahlaki olarak hak ve yükümlülüklerle birbirlerine bağımlıdır. Fakat Durkheim'in organik dayanışma olarak gördüğü modern toplumu Marx çok büyük sosyal problemlerin olduğu bir sınıf mücadelesi olarak değerlendirirken Weber de haksızlık, adaletsizlik ve rasyonel bürokrasinin tahakkümünün varlığına karşı korkularını dile getirmiştir (Grabb 1984, Morrison 2006).

Ancak Durkhaim'a biraz daha yakından bakıldığında Marx ve Weber'in gördüğü sosyal eşitsizliklere duyarsız kalmadığı ve yakından ilgilendiği görülecektir. Durkheim daha farklı bir bakış açısı ile sosyal eşitsizliğin toplum dayanışmasına olan etkilerinden bahsetmiştir ve zaten Durkheim için her zaman en önemli konu toplumsal dayanışma olmuştur. Durkheim'in çalışmalarında satır aralarına yakından bakıldığında sosyal tabakalaşma ve eşitsizliğin doğas1 ve sonuçları hakkında Marx ve Weber'e paralel gözlemlerinin olduğu görülecektir. Durkheim'in tabakalaşma ve eşitsizlik hakkında görüşleri normal ve normların sarsıldığ anomik iş bölümü, modern toplumda devletin ahlaki ve moral koruyuculuk rolü, ekonomik problemler, meslek gruplarının ortaya çıkışı, toplumsal dayanışma ve eşitsizliğin geleceği gibi konu başlıkları etrafında şekillenmektedir (Grabb 1984, Grusky ve Sorensen 2001). Aşağıdaki satırlarda iş bölümü, anomik ve baskıcı iş bölümü, devlet, ekonomi ve meslek birlikleri kavramlarını çözümleyerek Durkheim'in işlevselci teori çerçevesinde tabakalaşmaya bakış açısını ele alacağız.

İş Bölümü: Durkheim İş Bölümü isimli ünlü eserinde şu soruları sormaktadır: Tek tek bireylerden oluşan topluluk nasıl toplum haline dönüşmektedir? Toplumsal varlığın koşulu olan fikir birliği (consensus) nasıl gerçekleşmektedir? Durkheim toplumların evrimini, birey toplum ilişkisini ve toplumdaki fikir birliğini iş bölümü olgusu temelinde açıklamaktadır. Toplumsal dayanışma iş bölümüne bağlı olarak gerçekleşmektedir. Çünkü düzen ve dayanışma bir toplumun devam edebilmesi için oldukça önemlidir. Modern toplumda düzen ve dayanışmanın kaynağı ise iş bölümü ve uzmanlaşmadır. Durkheim'a göre iş bölümü, "farklı ama bir bütün içindeki faaliyetleri yerine getiren kişi ya da 
grupları koordine etmeyi sağlayan, istikrarlı bir düzenlemeyi anlatır." (Kösemihal 1993, Durkheim 2006)

Tanımdan da anlaşılacağı gibi iş bölümü bir toplum içinde düzenlemeyi ve istikrarı sağlayan bir işleve sahiptir. Durkheim'e göre, iş bölümünün gerçek işlevi "iki ya da daha fazla insan arasındaki bir dayanışma duygusu yaratmaktır” (Swingewood, 1998, s. 140). Durkheim için, toplumdaki iş bölümü görevler veya sorumluluklarda belli ölçüde uzmanlaşmayı gerektirdiği için maddî nitelikte bir toplumsal olgudur (Ritzer, 1992). Durkheim, toplumsal evrimi iş bölümü olgusu temelinde açıklamaktadır. Toplumların evrimsel süreci içinde iş bölümüne bağlı olarak gelişen ideal tipte iki tür toplumsal yapıdan söz etmektedir: Birincisi mekanik dayanışmacı, ikincisi ise organik dayanışmacı toplum tipidir. İşbölümünde meydana gelen değişimler toplumsal yapıda oldukça kapsamlı değişikliklere ve sonuçlara neden olmaktadır. Ortaya çıkan bu sonuçlar, aslında mekanik ve organik dayanışma arasındaki farklılıkları ifade etmektedir (Kösemihal 1993; Durkheim 2006).

Geleneksel toplumlarda görülen mekanik dayanışmaya bağlı olarak iş bölümü gelişmemiştir ve oldukça sınırlıdır. Sanayi toplumlarında ise organik dayanışmaya paralel bir şekilde iş bölümü çok ayrıntılı bir biçimde artmış ve uzmanlaşma ortaya çıkmıştır (Durkheim 2006, Kösemihal 1993).

İş bölümü normal şartlarda işleyen ideal bir durumu ifade etmektedir. Modern iş bölümünde ahlaki ve yasal kurallar normal şartlarda işlediğinde ve makam ve mevkiler adil bir şekilde hak edilmeye göre dağıtıldığında iş bölümü de normal seyri içinde devam edecektir. Eğer her bir fert iş bölümünde hak ettiği mevkiye ulaşmak için eşit şartlara sahipse iş bölümü de adil bir şekilde oluşacaktır. Normal şartlarda işleyen bir iş bölümü ortamında kural, yasa ve normlarının ihlali iş bölümünün işlevinin bozulmasına yol açacaktır. Modern İşbölümünde yeteri kadar ahlaki ve moral değerlerin olmaması anomik iş bölümüne ve adil olmayan bir iş bölümü de zorbalığın hüküm sürdüğü iş bölümü ortamına dönüşecektir (Grabb 1984, Kösemihal 1993, Durkheim 2006, Coser 2008, Ritzer 2011). Anomik ve zorbalığa dayalı iş bölümüne kısaca değinirsek:

Anomik İş Bölümü: İş bölümü insanlar arasındaki bağları sağlayamadığında moral çöküntü, kuralsızlık ve anomi ortaya çıkabilir. Anomik iş bölümü dayanışmayı sarsarak insanlar arasındaki karşılıklı katkı ve yükümlülükleri ortadan kaldırır, kanunsuzluk devreye girer ve sonuçta dayanışmanın yerini karşılıklı mücadele alır. Bunun en önemli örneği kapitalist ve işçiler arasındaki çatışmalardır. Her iki taraf da karşılıklı olarak uzlaşma yerine kavgay1 seçtiğinde anomik iş bölümü baş gösterir ve ekonomik kriz ortaya çıar. Durkheim'in bu yaklaşımı Marx'ın bahsettiği sınıf kutuplaşmasını hatırlat- 
maktadır ve Durkheim yaşadığı dönemde üretim araçlarının giderek çok az bir kesimin elinde toplandığının farkındadır. Üretim araçlarının küçük bir azınlığın elinde toplanması sağlıklı bir iş bölümü sisteminin kurulmasını zora sokmakta, sınıflar arasında karşılıklı saygı, güven ve ahlaki değerleri çıkmaza sürüklemektedir. Durkheim anomik iş bölümünün kutuplaşmaya neden olduğunu savunurken Marx bu durumun kapitalizmin doğasında olduğunu dile getirmiştir (Grabb 1984, Kösemihal 1993, Durkheim 2006 ).

Durkheim ile Marx arasında bir diğer benzer tema da Marx, kapitalist iş bölümünün işçiler arasında yabancılaşmaya neden olduğunu düşünürken Durkheim' da anomik iş bölümünün çalışanları onur kırıcı bir duruma düşürüp makineleştirdiğinden bahseder. Ancak Marx ve Durkheim arasındaki fark iş bölümüne yaklaşımlarından kaynaklanmaktadır. Marx sorunun çözümü için kapitalist iş bölümünün ortadan kaldırması gerektiğini düşünürken Durkheim modern toplumda iş bölümünün gerekli olduğunu ancak iyileştirmeler yapılması gerektiğini ifade eder. Durkheim'a göre iş bölümü toplumun ayrılmaz bir parçasıdır (Grabb 1984, Durkheim 2006).

İş bölümünü kaldırmak yerine her birimiz yaşadığımız toplumda en iyi şekilde kendi üzerimize düşen görevleri yapmakla mükellefiz. Herkesin eşit derecede önemli rolleri oynaması mümkün değildir. İnsanlar toplum içinde kendi üzerine düşen yükümlülügü yerine getirip katkı yaptığ 1 ve bu duyguyu taşıdığında eşitlik gereksizdir. Durkheim'a göre asl olan haklar, ödevler, ahlaki ilkeler ve rollerdir. Her insanın geniş bir sosyal ufka sahip olması gerekmez, eylemlerinin bir amacı olduğuna dair bir bilince sahip olması yeterlidir (Durkheim, 1893, s. 372-373; Grabb 1984, s. 80).

Baskıcı İş Bölümü: Durkheim için iş bölümünde anomiye yol açan şartları moral ve ahlaki düzenlemelerle gidermek esastır. Ancak, bu türden düzenlemeler anominin giderilip sosyal dayanışmanın sağlanmasında tek başına yeterli değildir. "Kuralların olması tek başına yeterli değildir ve bazen kuralların kendisi kötülüğün asıl nedeni olabilmektedir" (Durkheim, 1893: 374; alıntılayan Grabb 1984: 80). Gerçek ahlaki değerler ile resmi kurallar karşıllklı olarak uyumlu olmalıdır. Geçerli olan kurallar gerçek ahlaki değerlerle uyumlu olmadığında ve bu kurallar küçük bir azınlık tarafından zorbalık ve güç kullanarak uygulandığında sosyal dayanışma hasar görecektir (Durkheim, 1893: 65, 107-108; alıntılayan Grabb, s. 80). Kısaca, ahlaki ve adil olmayan kuralların uygulanması anomik iş bölümüne yol açacaktır ve Durkheim bu durumu zorbalık olarak adlandırmaktadır. Modern toplumda sosyal dayanışma ve ahlakın temelleri bireyselcilik üzerinde yükselmektedir. Bireyselciliğin başat olduğu modern iş bölümünde birey doğal ve özel yeteneklerini sergileyip geliştirdiği takdirde iş bölümü normal seyri içinde işleyecektir. Ancak böyle bir sistem içinde bireyler kendini gerçekleştirecek ve bu sayede toplum için de işlevsel 
bir hale gelecektir. Diğer türlü baskıcı bir iş bölümü ortamında ise güç/iktidarı elinde bulunduranlar sadece kendi çıarları için hareket edecek ve bencil istekler normal iş bölümünü anomik bir iş bölümü ortamına dönüştürecektir. Baskıcı iş bölümü bir miktar sosyal dayanışmayı sağlıyor gibi görünse de bu dayanışma zamanla çökmeye mahkûm sakat ve sorunlu bir sosyal dayanışmadır (Durkheim, 1893: 376; Grabb, 1984: 81). Böyle bir sistem içinde insanlar küçük bir azınlığın bencil amaçlarına tabi olmaya zorlanacaklardır.

Durkhem'ın “baskıcı iş bölümü” Marx'ın üretim araçlarına sahip olanlarla işçi sınıfı arasındaki çatışmaya benzer bir yaklaşımdır. Durkheim baskıcı iş bölümü ile sınıflar arasındaki mücadeleye gönderme yapmaktadır. Ancak, Durkheim Marx'da olduğu gibi sinıf mücadelesi üzerinde derinlemesine yorum yapmaz ve sadece bu ilişkinin normal iş bölümünü tehdit ettiğini söyler. Durkheim'in sosyal eşitsizlikle ilgili bu yaklaşımı bazılarının iddia ettiği gibi ne kapitalist ekonomik ve siyasal düzeni bir savunma ne de bir özür dilemedir. Durkheim'a göre baskıcı iş bölümü tüm toplumu tehdit etmektedir ve ne pahasına olursa olsun ki bu şiddete başvurmak da dâhil olmak üzere elimine edilmesi gereken anomik bir durumdur (Durkheim, 1893: 378; Grabb, s. 81).

Durkheim anomik iş bölümünü rayına oturtmak için gerekirse şiddetin de kullanılabileceği üzerinde durmuştur ancak Marx'dan ayrıldığı en önemli nokta şiddete başvurmadan değiştirilebileceğini düşünmektedir. Baskıcı sosyal eşitsizlik ve anomi temelde bir yönetim sorunudur. Yetersiz düzenleme anomiye ve haksız, hukuksuz düzenleme de baskıcı sosyal eşitsizliğe neden olmaktadır. Modern dünyada devlet idare hukukunun en önemli aktörüdür. İş bölümünün karmaşıklaşması ile yasal düzenlemeler de çok daha karmaşıklaşmiştır.

Weber'de olduğu gibi, Durkheim'a göre de modern toplumlarda devlet en merkezi organdır. Devlet aygıtının yerine getirdiği işlevler yönetimden, adalete, eğitime, sağlığa, kamusal yardımlara ve savunmaya kadar tüm alanlarda en önemeli işlevleri yerine getirmektedir.

Devlet aygitı tüm bu alanlarda yasa ve kurallar oluşturup aynı zamanda tüm bu kuralların ahlaki ve adil olmasını sağlamada da en önemli aktördür. Normal şartlarda devlet yöneticileri de ahlaki olarak tüm toplum önünde rol modelidir. Böylece, devlet politikalar oluşturarak toplumda bireylerin birbirlerine karşı hak ve sorumluluklarını düzenler (Durkheim, 1893:222-223, Grabb, s. 82).

Devlet, Ekonomi ve Meslek Birlikleri: Durkheim devletin en önemli işlevinin ekonomi olduğunu belirtir. Çünkü ileri derecede karmaşıklaşmış iş bölümünde devletin ekonomik rolü ihmal edilemeyecek derecede önemlidir. Ancak çok karmaşıklaşmış ekonomik düzende devlet yöneticilerinin her so- 
runa çözüm bulmaları söz konusu değildir. Ayrıca, devlet yöneticilerinin ekonomik işleyişe müdahale etmeleri muğlâk bir alandır (Durkheim, 1893: 216; Grabb, 1984, s. 83). Durkheim devletin gerektiğinde ekonomiye müdahale etmesinin gerekli olduğunu savunur fakat Durkheim, sanayi ve ticari faaliyetlerin normal seyrinde işlemesi söz konusu olduğunda devlet aygıtlarının araya girip düzenleme yapmasının olası olmadığına inanır. Devletin ekonomik alanda ahlaki ve moral düzenlemelerden dışlanması ve ekonomik alanın çok karmaşıklaştığı için yetersiz kalması iş bölümünü tehdit eder. Ekonomik yapı ahlaki kısıtlamalardan bağımsızlaştığında ve devlet aygıtlarının da yeterince düzenleme yapmada yetersiz kaldığında sınıf çatışmaları ve sosyal adaletsizlikler nasıl çözülebilir? Durkheim'ın bu soruya yanıtı meslek örgütleridir (Durkheim, 1896: 203, 1902,28-29; Grabb, s. 83).

Durkheim meslek örgütlerinin sendika veya dernek olmadığını belirtmekte ve meslek örgütlerine özel çıkarlardan çok toplumun genelinin çıkarını gözeten bir misyon yüklemektedir. Meslek birlikleri birey ile devlet arasında aracı konumundadır. Meslek birlikleri ekonomik alanda moral düzenlemelerle ilgilenir çünkü her biri ekonomik alanın birer parçasıdır. Patronlarla işçiler arasında aracı rolü oynarlar ve düzenlemeler yapmada aracıdırlar. Durkheim meslek gruplarının zamanla gelişerek birey ve devlet arasında aracı bir rol oynayacağını endüstriyel çatışmaları düzenleyerek düzeni sağlayıp dayanışmayı tesis edeceğini öngörmüştür (Grusky ve Galescu, 2004).

"Durkheim toplumsal patolojileri çözecek temel reform olarak meslek birliklerinin geliştirilmesini önerir. Mülk sahipleri ve işçiler arasındaki çıkar çatışmasının ortak bir ahlaktan yoksunluk sonucu ortaya çıktığı görüşündedir. Durkheim, bu birleştirici ahlâkı sağlayacak yapının "tek bir grup içinde birleşmiş ve örgütlenmiş aynı sanayi içindeki aktörleri" kapsayacak meslek birlikleri olduğunu ileri sürer (1893). Böyle bir organizasyon, Durkheim'a göre, sadece mülk sahipleri, idareciler ve isçiler arasındaki ayrılıkları artırmaya hizmet eden sendikalar ve işveren birlikleri gibi organizasyonlardan farklı ve üstündür. Bu kategorilere dâhil ortak bir örgütlenme içindeki insanlar, birleştirici bir ahlâk sistemine ihtiyaçları olduğu kadar, ortak çıkarları bulunduğunu da kabul edeceklerdir. Bu ahlâk sistemi, oluşturduğu kuralları ve yasalarıyla, hem modern toplumun atomlaştırma eğilimini engellemeye yardımcı olacak, hem de kolektif ahlâkın önemindeki azalmanın önünü kesecektir" (Ritzer 1992, s. 14).

Durkheim gelecek hakkında iyimserdir. Ahlak ve adalet duygusu sosyal dayanışmayı sağlayacaktır. Durkheim yaşadığı dönemde ortaya çıkan şiddetli sınıf çatışmalarının geçici bir anomi durumu olduğunu düşünmüştür. İş bölümünün evrimleşmesi ile birlikte anormal formlar yerini düzenli işleyen bir iş bölümüne bırakacaktır. Geçmişte kast sistemi yerini bireysel başarıya bı- 
rakmıştır. Devlet sosyal yardım programları geliştirerek yoksulluk sorununu hafifletecektir (Grabb, s. 84).

Durkheim'ın iş bölümü ile Marx'ın sosyalizme geçiş aşaması arasında yüzeysel bazı benzerlikler vardır. Örneğin iş bölümünde mülkiyet sahipliğinin, ödül ve mevkilerin eşitliği söz konusu olmasa da iş bölümünde firsat eşitsizliğinin giderilmesi Marx'a yüzeysel olarak benzemektedir. Durkheim'a göre sorun ekonomik sistem değil sosyal dayanışmanın hasar görmesinden kaynaklanmaktadır. Her ikisi de dayanışmaya önem vermektedir fakat ideal sosyal dayanışmaya ulaşma yollarında nerdeyse birbirine zıt konumdadır (Grabb s. 85).

"Durkheim toplumun durumu ile ilgili endişesinde Marx'a benzer. Durkheim, modern toplumu kuralsızlık yüzünden sağlıksız olarak görürken, Marx bu durumu yabancılaşma olarak ele alır" (Wallace, s. 46).

Durkheim ve Weber'in tabakalaşmaya yaklaşımları mukayese edildiğinde her ikisi de aynı yıllarda yaşamış olmasına rağmen birbirinden habersizdi. Çalışmalarında çok yakın benzerlikler olmasa da bir kaç nokta üzerinden mukayese yapılabilir. Sosyal eşitsizlikte güç/iktidar kavramı Weber'in üzerinde önemle durduğu bir konudur. Weber modern toplumda gücün sadece üretim araçlarından ve mülkiyet sahipliğinden kaynaklanmadığını ve siyasi, kültürel, dini vs gibi farklı güç kaynaklarının bulunduğunu ve sosyal eşitsizlikte farklı güç konumlarının da kritik önemde olduğunu belirtir. Bu açıdan bakıldığında Durkheim'a göre de modern toplumda güç sadece çok küçük bir azınlığın elinde toplanmamış ve farklı konumlardan kaynaklanan güç merkezleri ortaya çıkmıştır. Bir diğer benzerlik de Durkheim'ın tartıştığı meslek gruplarıdır ve modern toplumda birey ve devlet arasında önemli bir güç merkezidir (Grabb, s. 87).

Her iki sosyolog da devletin önemine değinmiştir. Ancak Durkheim devlet yöneticileri ile ilgili iyimser bir yaklaşıma sahipken, Weber devlet yöneticilerinin de baskıcı ve devlet olanaklarını kendi çıkarları için kullanıp diğerlerini bask1 altına alabileceklerini dile getirmiştir. Bir diğer konu ise devletin gücüdür. Weber bu konuda çokça yazmıştır ancak Durkheim için güç mücadelesi ve bunun sonucunda sosyal hayatın şekillenmesi merkezi konumda değildir. Durkheim'a göre bu sınıf çatışması ve gücün kötüye kullanılması sosyal dayanışma ve ahlaki sarsıntıdan kaynaklanmaktadır (Grabb s. 87-88).

Yukarıdaki satırlarda da değinildiği gibi “Durkheim'in betimlediği patolojiler anomi, iş dünyasının yapısındaki eşitsizlik (yanlış konumlardaki yanlış insanlar) ve iş dünyasındaki yetersiz örgütlenme (irtibatsızlık) olarak sıralanır. Durkheim bir reformistti, yoksa bir radikal veya devrimci değil. Nitekim sosyalizm üzerine bir kitap yazarken, amacı devrimci bir öğretiyi ana-hatlarıyla 
ortaya koymak değil, aksine onu toplumsal bir olgu olarak araştırmaktı" (Ritzer 1992, s. 14)

Durkheim komünist devrim konusunda daha özel bir konumsa yapar:

"Tüm mülkiyet sisteminin bir mucizeyle bir gecede tamamen dönüştürüldüğünü ve kolektivist bir formülle üretim araçlarının bireylerin ellerinden alınıp tamamen kolektif bir mülkiyete dönüştürüldüğ̈nü varsayalım. Bu durumda bile bugün çevremizdeki, tartışmakta olduğumuz bütün problemler yine de var olmaya devam edecektir" (Ritzer 1992, s. 14).

Özetle, Durkheim yazılarında tabakalaşma ve eşitsizlik konuları sorunu üzerinde durmuştur. Tabakalaşma sorununu ele alırken iş bölümünün anormal biçimlerinin eşitsizliğe yol açtığını iddia etmiş ancak anormal işbölümü biçimlerinin geçici olduğunu ileri sürmüştür. Durkheim mutlak eşitliğe inanmayan bir sosyologdur. İş bölümünde ortaya çıkabilecek haksızlıkları gidermek için meslek birlikleri ve devletin önemine değinmiştir.

\section{Modern Yapısal İşlevselci Teori ve Tabakalaşma}

Modern yapısal işlevselciler en güçlü tabakalaşma teorisini Durkheim'dan 50 yıl sonra Amerika'da geliştirdiler. Durkheim'in modern işlevselci tabakalaşma teorisinde çok büyük bir etkisi oldu. Modern işlevselcilerin toplum imgelemleri Durkheim'da olduğu gibi toplum birbirine bağımlı alt parçalardan oluşan bir sistemdir ve her bir parçanın sistem içinde yerine getirdiği bir işlevi vardır. Tıpkı Durkheim'da olduğu gibi modern fonksiyonalistlerde de sosyal uyum, işlevsel karşılıklı bağımlılık ve değerler önemlidir. Modern işlevselciler aynı zamanda birkaç önemli noktada Durkheim'dan ayrılmaktadır (Kongar 1985, Coser 2008, Ritzer 2011).

Parsons Amerika'da en önemli temsilcisi olarak Durkheim'ın çalışmalarını yeniden yorumlamıştır. Parsons Durkheim ve Weber'in çalışmalarını kendi bakış açısından yorumlayarak yeni bir işlevsel bakış açısı geliştirmiştir. Aşağıdaki satırlarda 1950'li yıllardan sonra geliştirilen modern yapısal işlevselci ekolün temel kavramlarına değineceğiz ve buradan hareketle Parsons'un tabakalaşma sorununu nasıl ele aldığını kısaca özetlemeye çalışacağız. Bu çalı̧̧manın son bölümünde toplumsal tabakalaşma açısından işlevselcilik içinde çok önemli bir yeri olan Davis ve Moor'un tabakalaşma teorisini özetleyeceğiz.

Modern Yapısal İşlevselcilikte Temel Kavramlar: Yapısal işlevselcilere göre toplumda her organın farklı bir fonksiyonu vardır ve farklılaşmış birimler birbirleri ile bağlantılıdır. İşlev/fonksiyon kavramı toplum içinde ihtiyaçların giderilmesi için yapılan faaliyetler ve bir parçanın bütüne yaptığı katkıdır. Toplum sistematik bir uyum içinde çalışan bir bütündür. Toplum bir sistemdir. 
Toplumda bulunan kurumların, aile, eğitim, siyaset, ekonomi, din vb. ilişkiler ağının iyi öğrenilmesi, sistemin işleyişinin iyi anlaşılmasını sağlar. Her kurumun varlığ birbirine bağl1 ve birbiri ile ilişkilidir(Kongar 1985, Cuff 2006, Coser 2008, Ritzer 2011).

Yapısal işlevselciliğin temel varsayımlarını kısaca özetlediğimizde: Bir sistemin öğeleri fonksiyonel olarak karşılıklı ilişki içindedir. Öğelerin birbirine bağımlılığı mutlaka söz konusudur. Bir sistemin öğeleri genellikle bu sistemin işleyişine olumlu katkıda bulunurlar. Değerler ve normlar sosyal hayatın temel elemanlarıdır. Sosyal yaşam anlaşmaları içerir mutabakatlar üzerine kurulur, zorunlu olarak girifttir ve iç içe geçmiş ilişkileri barındırır. Sosyal yaşam eşgüdümlüdür ve ahenk üzerine kuruludur. Toplumlar yasal otoriteyi tanır. Sosyal sistemler bütünleştirir ve kalıcı olmaya eğilimlidir(Ritzer 2011).

“İşlevselcilikte toplum hiçbir kısmının bütünden ayrı olarak anlaşılamayacağ1 ve birbirleri ile ilişkili kısımlardan oluşan bir sistemdir. Bu görüşe göre herhangi bir kısımdaki değişim, sistemin diğer kısımlarında bir miktar dengesizliğe ve bir ölçüde de bir bütün olarak sistemin yeniden düzenlenmesine yol açar. İşlevselcilik, biyoloji bilimindeki organik sistem modeline dayalı olarak geliştirilmiştir. İşlevselcilerin 'bir toplumsal sistemin birbirleri ile ilişkili k1sımları ' ifadesi bir hava alanına bakılarak anlaşılabilir. Burada kısımlar, uçak biletleri ve rezervasyon personeli, bakım grubu, pilotlar, hostesler, yolcular, denetim kulesi personeli, restoran işçileri, yük taşıyıcılar ve benzerleridir. Bütün bu kısımlar birbirleri ile ilişkilidir ve bunların birbirlerine karşıllklı olarak dayalı olduğunu anlamak için birinde bir tedirginliğin olduğunu düşünmek yeterlidir. Havaalanın bir sistem olarak dengesizliğe yol açacak kötü hava şartlar1 veya radar denetim sisteminin iyi çalışmaması gibi değişiklikler olduğunda sistem geçici olarak işlemez hale gelerek dengesizlik doğuracak ve yeniden düzenlenerek denge tekrar sağlanacaktır" (Wallace ve Wolf 2012, s. 43).

"Yapısal işlevselciler sosyolojik analizlerinde daha çok demografik ve ekolojik değişimler, iç göçler, kentleşme, alt-kültürler ve sapan davranışlar, toplumsal tabakalaşma, toplumsal hareketlilik gibi konulara odaklanırlar. Yapısal fonksiyonel yaklaşıma göre her yapı, bir fonksiyon sahibi olduğu için gelişir. Yoksa yapılar var olduğu için belli fonksiyonlar ortaya çıkmaz. Başka bir deyişle, fonksiyonlar, yapılardan önce ortaya çıkar ve kendilerini yerine getirecek yapıların yaratılmasına yol açarlar. Yapılar fonksiyonları değil, fonksiyonlar yapıları yaratır. Fonksiyonel olma, bir ihtiyacı karşılama ve öteki parçalarla ahenkli bir bütünleşme demektir. Bu yüzden her toplumsal birim, yapısal fonksiyonel modele göre, toplumsal sistem için vazgeçilmez niteliktedir" (Kongar, 1985, s . 153). 
“Bu bakış acısına çok zaman 'yapısal işlevselcilik' adının verilmesine sebep, bir toplumsal sistemin ayakta kalabilmesi için, karş1lanması gereken işlevsel zorunluluklar veya gereksinmeler (needs) ile bu gereksinmeleri karş1lama durumunda olan yapılar üzerinde odaklanmış olmasıdır. Bu görüşe göre, toplumsal sistemler, varlıklarını sürdürebilmek için, bazı işleri yapmak eğilimindedir ve dolayısı ile sosyolojik çözümleme, bu işleri yapacak veya bu "gereksinmelere" cevap verecek toplumsal yapıları aramak durumundadır" (Wallace ve Wolf, s. 42).

Yapısal işlevselci tabakalaşma teorisine en net ve önemli katkı Davis ve Moore'dan (1947) gelmiştir ancak Parsons da çalışmalarında tabaklaşma sorunu üzerinde bir hayli durmuştur. İlerleyen paragraflarda kısaca Parson'un tabakalaşma kuramına değindikten sonra Davis ve Moore'un kuramını özetleyeceğiz.

\section{Parsons ve Sosyal Tabakalaşma}

Parsons işlevselci ekol içinde toplumsal tabakalaşma konusuna sıkça değinmiştir. Tabakalaşma konusunu ele alışında Parsons'un hareket noktası Davis ve Moore'dan farklı değildir. Parsons'a göre de toplumsal tabakalaşma her toplumda gözlemlenen bir zorunluluğa cevap verir. Zira örgütlenmiş sistemlerde gerekli hayati bir işlevi yerine getirir. Tabakalaşmanın temeli, her toplumun iş bölümüne göre zorunlu bir düzenlemeye başvurması olgusunda yatar. Fakat iş bölümünden çıkan her hareket biçimi eşit önemde değildir. $\mathrm{Bu}$ eylem biçimlerinin hiyerarşik sırlamasında Davis ve Moore'un kabul ettikleri "fonksiyonel yarar" ilkesi Parsons için her yer ve zamanda geçerliliğe sahip değildir (Parsons, 1940).

Parsons'a göre tabakalaşma sistemi toplumun doğrudan doğruya merkezi hâkim değerlerine bağlı olarak oluşur. Çünkü toplumdaki mevcut değerlerden her biri, toplumsal faaliyetlerin kendisine göre ölçüldüğü "prototip model" oluşturur. Diğer bir ifade ile her toplumda bulunan dinsel, teknik, bilimsel, siyasal vb değerleri arasında biri, toplumca esas değer ölçütü olarak kabul edilmekte ve diğer faaliyetler buna göre hiyerarşik bir sıralamaya tabi tutulmaktadır.

Davis ve Moore ile karşılaştırıldığında Parsons tabakalaşmaya çok daha genel, teorik ve soyut yaklaşmaktadır. Diğer çalışmalarında olduğu gibi Parsons tabakalaşmayı soyut bir bakış açısı ile ele aldığı için tabakalaşma ile ilgili yazdıklarından ampirik olarak test edilebilir hipotezler türetmek oldukça güçtür. Parsons tabakalaşmayı daha yakından anlayabilmek için iki kavramın önemli olduğunu ileri sürmüştür. Parsons'a göre bir toplumda yaşayan insanlar diğer insanları yaşadıkları toplumda geçerli olan değerleri nasıl içselleştirip 
yaşadıklarına göre değerlendirmeye tabii tutar. $\mathrm{Bu}$ da her toplumda saygınlık açısından her zaman bir hiyerarşinin var olması demektir (Modern Theories of Social Stratification, s. 121, Erişim Tarihi, 2014).

Parsons maddi olarak zenginlik ve gücün farkındadır ancak Parsons'a göre bunlar ikinci derecede önemlidir. Parsons, Davis ve Moore ile aynı sonuca ulaşmıştır fakat Parsons'a göre işlevsel olarak en önemli mevkilerin belirlenmesinde toplumun ortak hâkim değerleri etkilidir.

Parsons toplumda saygı duyulan değerler çerçevesinde gerçekleştirilen iş ve rolleri en çok saygı duyulanından en az saygı duyulanına göre sıralamıştır. Parsons her toplumsal sistemde dört alt işlevsel sistemin gerekliliği üzerinde durmuştur. Bunlardan ilki her toplumun yaşayabilmesi için bulunduğu çevreye adapte olmasıdır (adaptation of the environment). İkincisi, amaçların gerçekleştirilmesi (goal attainment), üçüncüsü uyum (integration) ve dördüncüsü de gizil kalıpların korunup (latent pattern maintanance) sürdürülmesidir (İngilizce ilk harflerin kısaltılması ile bu dört alt sistem Parsons sosyolojisinde AGIL şeklinde isimlendirilmektedir).

Birincil somut kurumlar bu işlevsel gereklilikleri yerine getiren bir toplum için sırası ile iktisat, devlet, legal sistem ya da bazen din, aile, okul ve kültürel kurumlardır. Bu saydığımız her bir kurum toplumun yaşayabilmesi için gerekli olan işlevleri yerine getirmektedir. Örneğin iktisadi kurum çevreden kaynak sağlayıp toplumun ihtiyacı olan mal ve hizmetleri yerine getirir. Devlet ya da siyaset amaçları tanımlar ve amaçlara ulaşmak için meşru yollar gösterir. Hukuk ve din herkesçe kabul edilen kural ve ahlaki ölçütler koyarak sosyal sistemin bütünleşmesini sağlar. Aile ve eğitim kurumu fertleri sosyalleştirip ihtiyaçlarını karşılayarak toplumdaki rollerini yerine getirmelerini bekler (Modern Theories of Social Stratification, s. 121, Erişim Tarihi, 2014).

Parsons toplumsal tabakalaşmayı bu dört alt sistem ile ilişkilendirerek inşa etmektedir. Parsons'a göre toplumda çeşitli kurumlar kendilerince farklı değer sistemlerini ön plana çıkarmaktadır. Toplumlar bu dört alt sistemden hangisini ön plana çıkarttığına göre tabakalaşma açısından farklılık gösterir. Örneğin devletin daha baskın olduğu bir toplumda, ortak değerler sistemi devlet etrafinda belirginleşecektir. Bu nedenle birincil önemdeki kurum ya da kurumların belirlediği değerleri en iyi şekilde yansıtan birey ya da bireyler en saygın durumda olacaklardır ve bu durum da zenginlik, eğitim ve gelir ile yakından ilişkilidir.

Parsons'un tabakalaşma temellendirmesini tekrar özetlediğimizde:

1. Başka insanlar toplum içindeki bir bireyi önem atfedilen moral değerlere göre değerlendirir ve bunun sonucunda bu bireyin tabakalaşma sistemi içindeki yeri ortaya çıkar. 
2. Moral değerlendirme toplumda ortak olan değerlerdir.

3. Ortak değerler sistemi toplumda ön plana çıkmış olan kurum ya da kurumlar tarafından şekillenir

4. Sonuç olarak birincil önemdeki kurum ya da kurumların belirlediği değerleri en iyi şekilde yansıtan birey ya da bireyler en saygın bir durumda olmanın yanında yüksek gelir, eğitim ve zenginlik gibi ödülleri de elde edeceklerdir.

Burada not edilmesi gereken bir başka boyut otoritenin (güç) elde edilmesi ile ilgilidir. Parsons'ta otoritenin elde edilişi mesleki yapıdaki işlevsel öneme göre belirlenmektedir ve bu da statü kazanımı yolu ile gerçekleşir. Amerika ve Çin Örneğinden yola çıkarak Parsons'un bu düşüncelerini daha da somutlaştırmaktadır. Yukarıdaki paragraflarda dört alt sistemden hangisinin ön plana çıktığı üzerinde durulmuştu. Parsons'un dört alt sistemini ve buna karşıllk gelen somut kurumlar incelendiğinde, örneğin, Amerikan toplumunda adaptasyon ve buna karşılık gelen ekonomi kurumu hâkim kurumdur. Sonuç olarak toplumsal tabakalaşmayı belirleyen kıstaslar ekonomik temellidir ve ortak değerler sistemi mesleki hiyerarşi etrafinda belirginleşmektedir. Saygınlığ1 yüksek mesleklerin gereğini yerine getiren bireyler yüksek statülü mesleklere sahip olacak ve yüksek gelir elde edecektir. Amerika ile mukayese edildiğine örneğin Çin dört alt sistemden amaçların gerçekleştirilmesine (goal attainment) ya da politik kurumların ekonomik kurumlara göre daha baskın olduğu bir değerler sistemine önem atfetmektedir. Çin'de devlet bürokrasisinin değerlerini içselleştiren ve devlet görevlilerine yakın olan bireyler yüksek statüye sahip olacak ve sonuçta yüksek gelir elde edecektir. Benzer bir durum İran için de söylenebilir. İran'da devrimden sonra dini ön plana çıkaran mollaların tanımladığı değerlere sahip olup mollalara yakın olmak yüksek saygınlığa ve gelire neden olmaktadır ((Modern Theories of Social Stratification, s. 122, Erişim Tarihi, 2014). Amerika'da iş adamları, Çin'de ise devlet elitleri ve onların etrafındakiler en yüksek ödüle sahiptir. Ancak çatışmacı yaklaşımı savunanlar neden böyledir diye sorduğunda Parsons'un cevabı işlevsel önem olacaktır. Parsons bireysel çıkar ve sınıf çatışmasının farkındadır ancak diğer işlevselcilerde olduğu gibi bireysel çıkarlar ikincil önemdedir.

Parsons (1968: 61) Wright Mills'in Ikktidar Seçkinleri (1974) kitabını eleştirisinde Mills'in öne sürdüğü tezleri eleştirmemiştir. Mills'in temel tezini tekrar hatırlatırsak Amerika'da azınlık bir grup elit ülkeyi kendi çıkarlarına göre yönetmektedir. Parsons, Mills'in bu görüşünü eleştirmemiştir. Buradaki temel nokta, güç toplumun genel çıkarı için değil, elitlerin kendi sınıf çıkarları için kullanılmaktadır. İşlevselcilikte olduğu gibi toplum yararından ziyade çoğunluğu dışarıda bırakan bir avuç azınlık bireyleri manipüle ederek sınıf çıkarla- 
rını sürdürmektedir. Bir başka ifade ile eğer Parsons'un varsayımını (aktörler sosyal sistem içinde sistemin işleyişine katkıda bulunur, elitlerin elindeki güç sosyal sistemin işleyişine katkı yapar) aldığımızda Parsons'un Amerikan tabakalaşma sistemi Mills'in İktidar Seçkinleri'nde anlattıklarına çok yakın şeylerdir. Burada Mills için kâbus olan olan şey Parsons'ta sosyal sistemin işleyişine dönüşmektedir. Çatışma yaklaşımı benimseyen Tumin de benzer bir ifade ile tabakalaşma sisteminin elitler için işlevsel olduğunu ileri sürmüştür ((Modern Theories of Social Stratification, s. 122, Erişim Tarihi, 2014).

"Parsons modern toplumda çatışmanın fiili varlığını hiç bir zaman ret etmemiştir. "Sınıf çatışması kesinlikle vardır... Sınıf çatışması, modern sanayi toplumuna özgüdür”. Ama burada önemli olan nokta, Parsons'un ve diğer işlevselcilerin kafasındaki sınıf çatışmasının, bir toplumsal tabakalaşma sisteminde başat yapısal öğeyi oluşturmamasıdır (Parsons, s, 329-333). Çatışma bir değişim kaynağı olmaktan ziyade toplumsal denetimin çökmesinin bir göstergesi, gelir, statü ve güçteki eşitsizliklere aykırı bir karışıklık seklinde kavranmaktadır. Parsons'un denge modeli gücün ve çatışmanın önemini en alt düzeye indirmiştir. Benzer bir bicimde sosyolojik çatışma modeli de uyum ve dengeye sık gönderme yapmaktadır. Gerek Parsons ve gerekse Merton, sosyolojinin çatışmayı vurgulayan teoriler ile uzlaşmaya ağırlık veren teorilere bölünebileceği argümanına karsı çıkmışlardır. Biyoloji analizini tercih eden Parsons, bir yanda organizmanın sağlığını temel alan, öbür yanda da organizmanın patolojisine öncelik veren iki ayrı teori bulunmadığına dikkat çekmektedir (Parsons 1975). Yine de sosyoloji akimi içerisinde, bu dikatomiyi kabul eden bir gelenek çıkmıştır" (Swingewood, s. 289). Sosyolojik işlevselcilik çatışmayı işlevsiz ya da bir 'hastalık' olarak kategorileştirme eğiliminde olmuş, çatışmanın toplumsal yapıların oluşması ve korunmasında oynadığı önemli yapıcı rolü göz ardı etmiştir.

"Luhman esas itibari ile Parsons gibi, gelecek konusunda iyimser değildir. Ona göre, modern dünya normların paylaşılabilmesine ve hatta değerlerin genelleştirilebilmesine müsaade etmeyecek kadar karmaşıktır" (Wallace ve Wolfe, s. 103).

Yapısal işlevselcilikte uyum, işlev ve değer gibi kavramlara yapılan aşırı vurgu toplumsal gerilimleri görmezden geldiği için eleştirilmiş ve bu eleştirilere karşıl1k Merton modern işlevselci ekol içinde toplumsal çatışma ve gerilimleri de incelemeye tabi tutmuştur. Merton geliştirdiği bir şemada gerilim yaratan mekanizmaları inceleyerek modern işlevselci gelenek içinde sosyal tabakalaşma konusuna dolayalı olarak değinmiştir.

"Merton`a göre anomi, kültürel amaçlar ile bunlara varmanın meşru yolları arasında bir kopukluktur. Bu çözümlemesini Birleşik Devletlere uygulayarak, 


\section{8 • YALOVA SOSYAL BİLIMLER DERGİSİ}

maddi başarının (para kazanma ile ilgili) çok önemsendiğini; buna karşılık, "bu amaca varmak için kullanılacak meşru yolların" o derecede belirlenmediğini göstermiştir. Bunun sonucu olarak ortaya çıkan kuralsızlık (anomie), genel olarak Amerikan toplumu için bozuk işlev ve ülke için de maddi başarı sağlama amaçlarına sahip olmayan topluluklar için özellikle bozuk işlev görmektedir. Böylece Parsonscu anlamda 'sistem içi bir gerilim' kaynağı olup, önemli ölçüde sapmaya yol açmaktadır. Merton modelini bir grafik ile gösterirken, maddi başarı amacının veya bu amaca varma yollarının kabul görmesi için '+' ve '-' işaretlerini kullanmıştır. Böylece beş uyum ya da sapma sekline varır. Böylece Merton bazı yapılardan kimin yararlandığını sorarak eşitsizlik sorununu ortaya çıkarmakta ve böylece Parsons'unkinden daha eleştirel bir görüsse yol açmaktadır" (Wallace ve Wolfe, s. 94).

"İnsan mutabakat veya işlevselci teoriyi ve çatışma teorisini bir paranın iki yüzü olarak gören Dahrendorf ve Coser ile ayni görüşte olabilir. Herhangi bir toplumsal düzenin temelinde mutabakat bulunması gerektiğini kabul etmek, bu kuramı muhafazakâr mı yapar? Parsons, işlevselciliğin, herhangi bir ideolojik anlam taşımadığını iddia ederken işlevselci yaklaşımın "politik muhafazakârlıkla hiç iliksisi olmadığını ve statükonun savunması olmadığını söylemektedir. Geçmişte gerilim ve çatışma toplumsal sistem için bozuk işlev olarak görüldüğünden ve patolojik bir durum olarak kuralsızlıktan kaçınılmak istendiğinden, toplumu çözümleme için işlevselci yaklaşım muhafazakâr bir yaklaşım olarak kullanılmıştır. İşlevselciliğin cezbettigi kişiler, gerçekte mevcut sistemden az çok memnun ve sistemin devamı konusunda tarafsız olmayan kişilerdir (Wallace ve Wolfe, 105).

“Özetlersek, işlevselcilik, çıkarlardan çok değerlere ağırlık vermektedir ve fikirlerin bağımsız önemini ve güç ile toplumsal kabul arasındaki bağları göstermekle beraber, gücün baskıcı yönlerini ve insanların birbiriyle çatışan amaçlarının anlamını ihmal etmektedir. Bunun gibi, toplumsal değişmeden fazla, toplumsal denetime önem vermekle, kargaşalık yaratıcı değişimi değil, düzenleyici (adjustive) değişimi çözümleyerek toplumun, değişme olmadan karşılanamayacak olan menfaat ve amaçları yerine, güven ve 'gereksinmelerine ağırlık vermektedir. Genel olarak süreçten çok yapıyı önemsemekte ve mikro sosyolojik çözümleme yerine, makro sosyolojik çözümlemeye yer vermektedir ( Wallace ve Wolf, s. 93).

\section{Davis ve Moore: Tabakalaşmanın Temel İlkeleri}

Davis ve Moore'e göre hiç bir toplumda mutlak anlamda bir eşitlik yoktur ve toplumsal tabakalaşma evrensel bir zorunluluktur. Tabakalaşmanın temel işlevi bireyleri sosyal yapı içerisinde belli mevkilere yerleştirmek ve moti- 
ve etmektir. Bir toplumda bazı konumlar fonksiyonel olarak diğer konumlara göre daha önemlidir, çünkü daha fazla çalışma, eğitim ve beceri gerektirmektedir. Toplumlar, yetenekli ve eğitimli kişileri işlevsel olarak daha önemli makamlara yerleştirip ödüllendirirler. Bunun sonucunda oluşan tabakalaşma sistemi de toplum için işlevseldir. Bir toplumda toplumsal tabakalaşmayı etkileyen iç faktörler şunlardır:

- Mevkilerin hangi düzeyde uzmanlaştı̆̆1,

- Hangi sosyal organizasyonun (aile, din, kapitalizm vs) başat bir öğe konumunda olduğu,

- Makam ve mevkiler arasında sosyal mesafenin ne kadar uzak veya yakın olduğu,

- Dikey hareketlilik için firsatların ne düzeyde olduğu

- Ve farklı sosyal sınıfların kendi menfaatleri için ne kadar organize olabildiği.

Tabakalaşmaya tesir eden dış dinamikler ise kültürel gelişmenin düzeyi, diğer toplumlarla ilişkiler ve toplumun büyüklüğüdür (Davis ve Moore 1945, s. 242).

Evrensel olarak her toplum içinde yaşayan aktörleri sosyal yapı içerisinde farklı makamlara yerleştirip motive etmektedir. Fonksiyonel bir mekanizma olarak toplum bir şekilde üyelerini farklı sosyal mevkilere sevk ederek bu mevkilerde görevlerini yapmaya teşvik eder. Toplum aktörleri iki farklı seviyede motive eder: Sosyal yapı farklı mevkilere uygun aktörleri yerleştirip onlardan yapılacak işlerin gereğinin yapılmasını bekler. Toplumun gelişmişlik seviyesi hangi derecede olursa olsun bu durum bütün faklı düzeyde gelişmiş toplumlar için geçerlidir (Davis ve Moore, s. 243).

Eğer toplumsal yaşamda farklı mevkilerin hepsi de eşit derecede önemli, benzer özellik ve yeteneklere sahip aktörler tarafından dolduruluyorsa o halde kimin hangi mevkiye gelip gelmediğinin bir önemi kalmayacaktır. Böyle bir durumun gerçekte olması pek mümkün değildir. Ancak gerçekte kimin hangi pozisyon ve mevkide bulunacağı önemlidir çünkü her zaman bazı mevkiler özel yetenek ve beceri gerektirecek ve işlevsel olarak diğerlerine göre daha önemli olacaktır. Bir toplumda bazı iş ve mevkilerin önemi hakkında uzlaşma vardır çünkü bu mevkiler çok çalışma ve özel yetenek gerektirir ve işlevsel olarak diğerlerine göre çok daha önemlidir. Sonuç olarak her toplumda işin önemi ve işlevine göre bir ödül sistemi olmak zorundadır ve bu ödüller beceri, çalışma ve işin işlevine göre dağılmaktadır. Bir toplumdaki ödüller ve teşviklerin farklı şekillerde dağılması kaçınılmaz bir zorunluluktur ve sosyal düzenin ayrılmaz bir parçasıdır, bu da neticede toplumsal tabakalaşmaya yol açmaktadır. Toplumda bir konum elde etmenin şartları farklı ise toplumsal 
tabakalaşma kendiliğinden ortaya çıkacaktır. Toplumlar bilinçli bir şekilde en önemli mevkilere en yetenekli kişileri yerleştirir. Ne kadar basit veya karmaşı olursa olsun topumlar kişileri saygınlık ve itibar bakımından ayrıma tabi tutar ve böylece bir şekilde eşitsizlik kurumsallaşmaya başlar (Davis ve Moore, s. 243-244).

Davis ve Moor'a göre, bir toplumda makam ve mevkilerin önem derecesini belirlemede iki temel faktör etkilidir:

- Bir mevki göreli olarak yüksek ödül derecesine sahipse (yüksek gelir ve itibar)

- Toplumda göreli olarak önemli bir işlevi yerine getiriyorsa

- ve bu mevkiye ulaşmak için uzun y1llar eğitim, zaman, emek ve beceri gerektiriyorsa

- bu söz konusu makam gelir ve itibar açısından önemli olacaktır. Çünkü sonuç olarak geliri yüksek, işlevsel olarak önemli ve bu konuma sahip olunması zaman, eğitim ve yetenek gerektirmektedir. Bir diğer ifade ile bir mevki işlevsel olarak önemli olmasına rağmen, kolayca doldurulabiliyorsa, yani bu mevkiyi doldurmaya hazır çok sayıda insan varsa o halde bu mevki işlevsel olarak çok önemli de olsa ödüllendirme derecesi göreli olarak düşük olacaktır. Diğer taraftan bir mevki göreli olarak çok önemli ise ve bu mevkiyi doldurmak kolay değilse yani uzun zaman eğitim, zaman ve yetenek gerektiriyorsa o halde ödüller de o derecede yüksek olacaktır. Bu nedenle bir mevkiinin işlevsel olarak önemli olması gerekli fakat yeterli bir şart değildir. Yine pek çok durumda çok fazla yetenekli ve potansiyeli olan insan var ancak çok uzun eğitim, emek ve staj gerektirdiği için elde edilmesi zordur ((Davis ve Moore, sayfa, 243-244).

Davis ve Moore'un dört temel varsayımını (Tumin (1953) tekrar özetlersek:

1. Her toplum içinde barındırdığı bireyleri sosyal mevkilere yerleştirir ve çalışmak için onları motive eder.

2. Bazı mevkiler diğerlerine göre işlevsel olarak daha önemlidir ve daha çok çalışma, eğitim ve yetenek vb. gerektirir.

3. Toplumlar mevkilerin işlevsel önemine göre uygun bireyleri (yetenekli, eğitimli vb.) daha üstün saygınlık ve kazanç sağlayarak motive eder.

4. Bu nedenle sonuçta toplum için gerekli ve işlevsel bir tabakalaşma sistemi ortaya çıkar. 
Ancak işlevsel önemlik bir toplumun içinde bulunduğu koşullar ve gelişmişlik düzeyine göre farklılık gösterir çünkü bir yerde işlevsel olan başka bir yerde olmayabilir. Tabakalaşmayı etkileyen iç dinamikler:

- Mevkilerin nasıl farklılaştığına

- Ne türden bir sosyal organizasyonun baskın olduğuna (din, aile, siyasi, kapitalizm)

- Mevkiler arasındaki sosyal mesafeye

- Dikey hareketlilik için fırsat eşitliğinin derecesine bağlıdır.

Toplumlarda işlevsel önem ve mevkileri dolduracak personel sayısını etkileyen sosyal faktörler din, devlet-hükümet, zenginlik, mülkiyet, emek ve teknik bilgi gibi faktörlerdir.

Din bazı toplumlarda birliği sağlamıştır ve bu nedenle din adamaları kutsal olanla ilişkili olduğu için çok yüksek bir ödül ve itibara sahiptir. Bunun en uç örnekleri Tibet Budizmi, ortaçağ Avrupa'sında Katolik papazlar, Hindistan'daki Brahmanlardır. Yasa yapma gücünü elinde bulunduran devlet görevlileri bir başka boyutudur. Burada da yine işlevsel önem ve yöneticilerin sayısının çok az olması söz konusudur. Zenginlik, para, mal ve mülk mevkilere ulaşmak için önemli bir aracıdır. Teknik bilginin artan önemi dolayısı ile teknik bilgi hem işlevsel önem hem de eğitim gerektiren modern topluma özgüdür (Davis ve Moore, s. 245-248).

Davis ve Moor'un bu tabakalaşma teorisi büyük tartışmalara yol açmıştır. Yukarıda da değindiğimiz gibi işlevselcilerde toplumsal tabakalaşma bütün toplumsal sistemlerin genel bir özelliğidir; dolayısı ile toplumsal eşitsizlik giderilemez bir şey olmakla kalmaz, toplumsal yaşamın sürekliliği açısından fiilen gereklidir de (Turner s. 41).

Davis ve More bir takım ödül ve ayrıcalıklara ulaşmak için tüm bireylerin eşit şartlar altında yarıştıklarını varsaymaktadır ve bu teori şartlarda ve sonuçlarda eşitliğin olduğunu varsaymaktadır. Bu varsayım ise pratikte geçersiz bir varsayımdır. Çünkü bireylerin ödüllere ulaşmak için eşit şartlar altında başlamadıkları bir gerçektir. Dolayısı ile Davis ve Moore'un tabakalaşma kuramı firsat eşitliği sorusuna yanıt veremez. Bu kuram toplumsal konumlar için girilen rekabete dayalı yarışın eşitlikçi bir çıkış noktasından başladığını varsaymaktadır, oysa şartlarda eşitlik olmazsa bu varsayım da kuşkuludur. İşin doğrusu bu kuram kültürel sermayenin mirası olan aykırı durumları hesaba katmamaktadır. Toplumsal konumlar için girilen rekabetçi yarış şartlarda eşitlik olmazsa eşit bir yarış olmaz ( Turner, s. 41).

Turner'in bir diğer eleştirisine göre toplumsal konumlara düşen ödüller işlevsel önemden çok iktidar çatışmalarının ve toplumsal kapalılığın ürünü de 
olabilir pekâlâ. Ayrıca, mesleki konumların saygınlığı çoğu zaman belgelemecilik (credentialism) ve toplumsal kapalılıkla sürdürülür, buradaki amaç işlevce önemli konumlara gelmeyi az sayıda aday için olanaklı kılarak geleneksel avantajları korumaktır. Dolayısı ile toplumsal tabakalaşmanın bir toplumsal sistemin idamesi açısından işlevsiz olduğu söylenebilir (Turner, s. 43).

Dördüncüsü, gözden çıkarılan kazanç, ise girildiğinde görece süratle yerine konulacağından, saygın bir meslek için göze alınan eğitimin büyük bir özveri olduğu pek de doğru değildir. Ayrıca olağan olan, öğrencilerin hoş bir üniversite ortamında bu mesleklerin eğitimini görmesine ana babanın veya devletin katkıda bulunmasıdır. Beşincisi, bu sav, eşitlikçi bir toplumdaki alternatife yerleştirme, güdülenme ve ödül sistemlerini değerlendirmeyi başaramaz. Toplumsal konumlar, kazandırdıkları gelirin dışında ve ötesinde, toplumsal saygınlık ve içkin ödüllere bağlı olarak da ödüllendirici olabilirler (Turner, s. 43).

\section{Toplumsal Tabakalaşma/Sosyal Eşitsizlik Ayrımı}

Toplumsal Tabakalaşma literatüründe tabakalaşma kavramını savunanlar genellikle işlevselciler iken tabakalaşmaya sosyal sınıf açısından yaklaşanlar da sosyal eşitsizlik kavramını kullanmayı tercih ederler. Bazı durumlarda ise her iki tarafın da işlevselci ve sosyal sınıf yaklaşımını sentezleyip birlikte kullandıkları da olur.

Geçtiğimiz yüzyılda sosyal sınıf kavramı tabakalaşma literatüründe çok büyük tartışmalara yol açmış, hakkında yüzlerce araştırma yapılıış ve tabakalaşma literatürünü hala meşgul ederek adeta bir hayalet gibi durmaktadır. İşlevselciler sosyal sınıf kavramına alternatif bir bakış açısı olarak tabakalaşma kavramını ön plana çıkarmaktadırlar. İşlevselcilere göre toplum farklı tabakalardan oluşan bir hiyerarşidir.

$\mathrm{Bu}$ bakış açısına göre bireyler belirlenmiş ölçütlere göre sıralandıktan sonra kategorilere ayrılır. Ölçütler araştırmacıya göre değişmekle birlikte en yaygını gelir, eğitim düzeyi ve mesleki konumdan hareket etmektedirler. $\mathrm{Bu}$ üç kategori birleştirilerek her mesleki kategori için bir derece belirlenir ve buradan da sosyo-ekonomik statüye ulaş1ır (Blau and Duncan, 1967). Bir diğer benzer yaklaşım mesleki kategorileri saygınlık boyutunda ele alarak sübjektif değerlendirmeler yolu ile ölçmektedir. Bu görüşe göre her meslek kategorisi puanlanıp saygınlık derecesine göre sıralanmaktadır. Toplumsal tabakalaşmayı çeşitli yönleri ile anlamak açısından bu türden yaklaşımlar çok faydalı olmuştur. Örneğin insanları gelir düzeylerine göre sıralayıp kategorilere ayırmak tabakalaşma ile ilgili bilgiler vermektedir (Goldhorpe ve Hope 1974). 
Yapısal işlevselcilerin tabakalaşmaya yaklaşımları da bireylerin belirlenmiş ölçütlere göre sıralanıp çeşitli tabakalara ayrıldıkları bir yapıyı ifade etmektedir. İşlevselcilere göre bireyler toplumda oynadıkları rol ve statülere göre bir hiyerarşiye tabi tutulmuşlardır. İşlevselciler mesleki kategorilerin tabakalaşama sisteminde en iyi gösterge olduğunu düşünmüşlerdir çünkü mesleki kategoriler gelir ve eğitim düzeyi gibi önemli tabakalaşma göstergeleri ile yakından ilişkilidir. Mesleki kategoriler aynı zamanda toplum içinde yerine getirdikleri işlevler açısından da tabakalaşmada önemli bir yer edinmiştir.

İşlevselcilere göre tabakalaşma sistemi kolektif uzlaşma sonucu bireylerin toplumda edindikleri meslek ve statülerine yerine getirdikleri işlevlerin önem derecesine göre oluşmaktadır. Meslekler toplumsal statünün temel belirleyicisidir. Toplumun tabakalaşma yapısının anlaşılmasında asli bir kategoridir. Zira gelir, eğitim düzeyi ve toplumsal statüyü yansıtan temel bir göstergedir. Meslek, bireyin sosyal statü edinmesi açısından olduğu gibi, bu statünün prestij düzeyinin oluşumu açısından da temel bir belirleyendir (Grabb, s. 98).

Tabakalaşma literatüründe işlevselcilerin mesleki kategorilere dayalı ölçümleri çoğu zaman "sosyal sınıf” kavramı ile karıştırılmaktadır. Marx ve Weber'in sosyal sınıf kavramsallaştırması ile işlevselcilerin mesleki prestije dayalı kavramsallaştırmaları birbirinden bir hayli farklıdır. İşlevselci tabakalaşmada elde edilen sonuç yani bireylerin mesleki prestijlerine göre sıralanmas1 sadece soyut bir sinıflamadır ancak Marxcı anlamada sosyal sınıf birbirleri ile ilişkide olan ve sınıf bilincine sahip gerçek bireylerden oluşmaktadır. Marx ve Weber'in çalışmalarında sosyal sınıf her zaman gerçek insanların birlikteliğinden oluşmamakla beraber çoğu zaman ilişkide olan insanlar kastedilmiştir. İşlevselci tabakalaşmada ise sınıflandırmalar analizler yapmak için istatsiksel bir gruplamadan öteye gitmez (Manza ve Brooks 1998).

Sınıf analizleri ile tabakalaşma analizleri sosyal eşitsizliğin farklı boyutlarına vurgu yaparlar. Sınıf analizleri yapanlar toplumsal sınıflar arasında ilişkilerin sonuçlarına eğilirken tabakalaşma analizleri yapanlarda gelir, eğitim düzeyi ve mesleki saygınlık skorlarının dağılımına odaklanırlar (Goldhorpe, 1974). Marx'ın sınıf tanımı üretim ilişkilerini esas alan bir tanım olarak işlevselcilerin tanımlarından tamamen farklıdır. Ayrıca, bazı yapısal işlevselciler Weber'in sınıf tanımının itibar(statü/prestij) ağırlıklı olduğunu ileri sürmektedirler ve Weberin sosyal eşitsizliğe yaklaşımı ile işlevselcilerin benzer olduğunu iddia ederler. Ancak, Weber'in sınıf tanımı tamamen ekonomik temelli ve piyasa şartlarında şekillenen ilişkiler sonucudur. Weber'deki statü grupları gerçek insanlardan oluşurken işlevselcilerdeki prestij şemaları gerçek gruplar değildir. Weber'de sınıf ve statü grupları aynı şey değildir ancak çoğu zaman çakışmaktadır (Grabb s. 99). 
Çatışma, Uyum ve Sosyal Eşitsizlik: Sosyal teoride toplumun çatışma üzerine kurulduğunu düşünen Marx ile uyum ve uzlaşma üzerine kurulduğunu düşünen işlevselciler sosyal tabakalaşmada birbirine zit iki kutubu oluştururlar. Diğer tabakalaşma teorileri de bu iki zıt yaklaşım arasında bir yerlerde değerlendirilebilir. Tabakalaşma teorilerini soldan sağa doğru düz bir çizgi etrafında gösterdiğimizde Marx çizginin en sol ucunda Parsons, Davis ve Moore'un kuramları da de çizginin en sağındaki uçta yer alacaktır. Weber'de yine çizginin sol tarafında yer alacaktır ancak Marx'da olduğu gibi aşırı uçta olmayacaktır. Durkheim ise çizginin sağında Weber'den sonra yer alacaktır. Durkheim işlevselciliğin kurucusu olsa da toplumda çatışmaların varlığına vurgu yapmış bir sosyologdur. Bilindiği gibi Marx'a göre insanlık tarihi aynı zamanda sınıf çatışması tarihidir (Grabb s. 100).

Marx ile karşılaştırıldığında Weber sosyal eşitsizliğin bir dereceye kadar uyum üzerine kurulduğunu düşünür. Sosyal eşitsizlik modern toplumda kurumsallaşmıştır ve oyunun kuralları bir dereceye kadar içselleştirilmiştir. Ancak, Weber fonksiyonalistlerde olduğu gibi mutabakat'ın abartılmaması gerektiğini düşünür. Eşitsizliğin kaçınılmaz olduğunu söylemek oyunun kurallarının belirlenip karşılıklı uzlaşma kurulduğu anlamına gelmez. Weber'e göre son tahlilde sosyal eşitsizlik bir grubun bir başka grubu veya grupları fiziksel güç ile egemenliği altına alıp güç ve iktidarı tekelleştirmesinden kaynaklanmaktadır. Sosyal eşitsizliğin bu zorlayıcı yönü toplumlar geliştikçe daha az görünür olmaya başlar ve modern toplumlarda oyunun kuralları belirlenerek kurumsallaşır. Weber'e göre yüzeyde istikrara kavuşmuş toplumsal hiyerarşilerin kökeninde bile çatışmalar yatmaktadır. Bazı vatandaşlar bu durumu kabullenip içselleştirirken diğerleri de alışkanlık, gelenek, korku ve alternatiflerin hayata geçmesi mümkün olmadığından düzene uyum sağlama yoluna gidecektir. Ayrıca uyum fikir birliği ve adaletin olduğu varsayılan toplumlarda bile farklı çıkar grupları arasında mücadele eksik olmaz (Grabb s. 101).

Marx ve Weber'e nispetle hiç şüphesiz Durkheim sosyolojisinde kolektif uzlaşma ve uyum merkezi önemdedir fakat bu Durkheim'in çatışmaları görmediği anlamına gelmez. Her şeyden önce kolektif şuurun modern zamanlarda zayıfladığının ısrarla üzerinde durur. Özgürlük ve firsat eşitliği kolektif vicdanda ahlaki bir duygu olarak paylaş1labilir fakat bunun ötesinde uyum ve uzlaşma zorlaşmaktadır. Çünkü modern iş bölümünün büyümesi, yasal ve ahlaki rehberliği de karmaşık hale getirmekte ve uzlaşma zorlaşmaktadır.

Yapısal işlevselci ekolün pek çok temsilcisi vardır ve hepsisinde toplum teorilerinde çatışmanın varlığını göz ardı ettiklerini söylemek doğru olmaz. Bununla birlikte, hiç şüphesiz yapısal işlevselci yaklaşımın genelinde çatışma birincil önemde bir mesele değildir. Diğer tüm teorilerden ayrıldığ 1 en 
önemli konu uyum ve uzlaşma sosyal yapının en temel yapı taşıdır. Parsons, Durkhem'ın modern dünyada ahlaki uzlaşmanın yitirildiği fikrine karşı çıkarak kolektif vicdanın değerler sistemi formuna büründüğünü iddia eder. Bu değerler sistemi erken çocukluk döneminden itibaren içselleştirilerek daha bireylerin sosyal eylemlerini şekillendirir. Dolayısı ile sosyal yapı geliştikçe değerler sistemi de sosyal yapı ile bir bütün halinde ve tutarlı olarak gelişip yerleşir. Yapısal işlevselcilere göre, tabakalaşma ya da sosyal eşitsizlik, her sosyal yapının doğal bir sonucudur. Tabakalaşma sosyal yaşamın evrensel bir yönüdür ve bilinen her toplumda tabakalaşma işlevsel olduğu için kaçınılmaz bir sonuçtur. Toplumda mesleklerin hiyerarşik düzeni ile ilgili yüksek düzeyde uzlaşma vardır (Grabb s. 101).

Yapısal İşlevselcilik ve Güç/İktidar Kavramı: Güç ve iktidar kavramı tabakalaşma ile çok yakından ilişkilidir ve tüm tabakalaşma üzerine düşünenler güç kavramı ile yüzleşmek durumundadır. Güç kavramı aynı zamanda devlet, iktidar ve otorite kavramlarını da gündeme getirmektedir. Yapısal işlevselciler tabakalaşma üzerine yazdıkları yazılarda güç ve otorite kavramı ile de yakından ilgilenmişlerdir. Yapısal işlevselciler demokratik ve çoğulcu bir toplum imaj1 çizerler ve tabakalaşma teorilerini de demokratik ve çoğulcu bir toplum anlayışından hareketle oluşturmuşlardır. Diğer tabakalaşma teorisyenleri gibi devlet kavramı üzerinde durmazlar ve hatta sıklıkla devlet kavramından da söz etmezler. Yapısal işlevselcilerde devlet kavramı diğerlerinde olduğu gibi tahakküm eden, hiyerarşik, merkezi ve bürokratik yapı değildir. Güç toplumun çeşitli kesimlerinde dağılmıştır ve bir grubun diğerlerini emir altına alması gibi bir durum söz konusu değildir. Devlet aygıtı da diğer güç merkezlerinden sadece bir tanesidir. Devlet değerlerlerin entegrasyonu ile oluşmuş bireyler tarafından seçilmiş ve toplum için işlevsel bir organdır. Devlet, hastane, üniversite, vakıf gibi kurumlardan bir tanesidir. Bireylerin çıkarlarını demokratik ve çoğulcu bir ortamda sivil toplum kuruluşları, baskı grupları, devlet organları ve siyasi partiler temsil eder (Grabb s. 105).

Tabakalaşma açısından bakıldığında yapısal işlevselciler demokratik ve çoğulcu bir toplumda sistemin açık bir sistem olduğunu ve dikey hareketlilik için şartların eşit olduğunu varsayarlar. Fırsat eşitliğinin olması hem devlet hem de bireyler için işlevsel bir amaca hizmet eder. Hem toplumun ihtiyac1 hem de bireylerin ihtiyacı karşılanmaktadır.

Yapısal işlevselciler güç konusunu sosyal düzenin sağlanması çerçevesinde ele alıp incelerler. Fonksiyonalistlere göre münferit olaylar dışında zor ve baskıya dayalı güç kullanmak sosyal düzenin sağlanmasında kullanılamaz çünkü son tahlilde zorlayıcı güç sosyal düzenin bozulmasına ve kesintiye uğramas1na neden olur. Yapısal işlevselcilere göre sosyal kontrol çoğunlukla yasal ve genel kabul görmüş kurallardan kaynaklanır. İşlevselcilerde anahtar kavram 


\section{6 • YALOVA SOSYAL BİLIMLER DERGİSİ}

sosyalleşmedir ve bu yolla bireyler herkes tarafından onaylanıp kabul edilmiş ve karşılıklı yarar sağlayıcı sosyal etkileşim çerçevesinde sosyal kural ve kontrol mekanizmalarını öğrenip içselleştirir. İşlevselcilerde insanlar iktidarda olanın korkusu ve baskısından dolayı kural ve normlara uymaz. Normlar toplum içinde fikir birliği sonucu neyin doğru neyin yanlış olduğunun uzlaş11ması ile oluşur. Dolaysı ile istikrarlı toplumlarda şiddet kullanmak çok nadir görülür ve zor kullanılmak zorunda kalındığında da yönetici ve yöneteli enler arasında meşruluk mutabakatı vardır (Grabb s. 106).

\section{Değerlendirme ve Sonuç:}

Toplumsal tabakalaşma ve soysal eşitsizlik sosyolojinin en önemli alt çalışma alanlarındandır. İşlevselci ekolün tabakalaşma yaklaşımı eleştiri konusu olmasına rağmen hala önemli bir paradigma olarak devam etmektedir. $\mathrm{Bu}$ makalede klasik ve modern işlevselcilerin tabakalaşmaya bakış açıları analiz edilmiştir. Bu çerçevede Durkheim'in tabakalaşma ve sosyal eşitsizliğe bakış1 işlevselci teori temelinde iş bölümünün anormal formları, dayanışma, devletin rolü ve meslek birlikleri ile ilişkisi dahilinde ele alınmıştır. Durkhem'e göre, modern toplumda iş bölümünün anormal biçimleri olan baskıcı ve anomik işbölümün haksızlığa ve dolayısı ile eşitsizliğe yol açtığını düşünmüş ancak anormal işbölümü biçimlerinin modern toplumda geçici olduğunu ileri sürmüştür. Durkheim ve daha sonra gelen modern işlevselciler mutlak eşitliğe inanmayan ve hatta eşitsizliğin işlevsel olduğunu düşünmüşlerdir. Durkheim tabakalaşma sisteminde ortaya çıkabilecek haksızlıkları gidermek için meslek birlikleri ve devletin önemine değinmiştir.

Modern yapısal işlevselciler en güçlü tabakalaşma teorisini Durkheim'dan 50 yıl sonra geliştirmişlerdir. Parsons, tabakalaşma sisteminin toplumun merkezi hakim değerlerine bağlı olarak geliştiğini düşünmüştür. Parsons'a göre her toplumda bulunan dinsel, teknik, bilimsel, siyasal değerlerin arasından toplumca esas değer ölçütü olarak kabul edilmekte ve diğer faaliyetler buna göre hiyerarşik bir sıralamaya tabi tutulmaktadır.

Davis ve Moore'e göre de hiçbir toplumda mutlak anlamda bir eşitlik yoktur ve toplumsal tabakalaşma evrensel bir zorunluluktur. Çünkü her toplumda bazı mevkiler fonksiyonel olarak diğer konumlara göre daha önemlidir. Tabakalaşmanın temel fonksiyonu bireyleri sosyal yapı içerisinde belli mevkilere yerleştirmek ve motive temektir.

İşlevselcilere göre toplumsal tabakalaşma bütün toplumsal sistemlerin genel bir özelliğidir, dolayısı ile toplumsal eşitsizlik giderilemez bir şey olmakla kalmaz, toplumsal yaşamın sürekliliği açısından fiilen gereklidir de. İşlevselcilik, çıkarlardan çok değerlere ağırlık vermektedir. Toplumsal Tabakalaşma 
literatüründe tabakalaşma kavramını savunanlar genellikle işlevselciler iken tabakalaşmaya sosyal sınıf açısından yaklaşanlar da sosyal eşitsizlik kavramı$\mathrm{n}$ k kullanmayı tercih etmektedirler. Bazı durumlarda ise her iki tarafın da işlevselci ve sosyal sınıf yaklaşımını sentezleyip birlikte kullandıkları da olur.

Yapısal işlevselcilerin tabakalaşmaya yaklaşımları da bireylerin belirlenmiş ölçütlere göre sıralanıp çeşitli tabakalara ayrıldıkları bir yapıyı ifade etmektedir. İşlevselcilere göre bireyler toplumda oynadıkları rol ve statülere göre bir hiyerarşiye tabi tutulmuşlardır. İşlevselciler mesleki kategorilerin tabakalaşama sisteminde en iyi gösterge olduğunu düşünmüşlerdir çünkü mesleki kategoriler gelir ve eğitim düzeyi gibi önemli tabakalaşma göstergeleri ile yakından ilişkilidir. Mesleki kategoriler aynı zamanda toplum içinde yerine getirdikleri işlevler açısından da tabakalaşmada önemli bir yer edinmiştir.

İşlevselcilere göre tabakalaşma sistemi kolektif uzlaşma sonucu bireylerin toplumda edindikleri meslek ve statülerine yerine getirdikleri işlevlerin önem derecesine göre oluşmaktadır. Meslekler toplumsal statünün temel belirleyicisidir. Toplumun tabakalaşma yapısının anlaşılmasında asli bir kategoridir. Zira gelir, eğitim düzeyi ve toplumsal statüyü yansıtan temel bir göstergedir. Meslek, bireyin sosyal statü edinmesi açısından olduğu gibi, bu statünün prestij düzeyinin oluşumu açısından da temel bir belirleyendir.

Güç ve iktidar kavramları tabakalaşma ile yakından ilişkilidir ve yapısal işlevselcilere tabakalaşma teorilerinde demokratik ve çoğulcu bir toplum imaj1 çizmektedirler. 


\section{KAYNAKÇA}

Blau, Peter ve Duncan Otis Dudley (1967). "The American Occupational Structure”, New York: Wiley.

Coser, Lewis A. (2008). “Sosyolojik Düşüncenin Ustalarl”, (Himmet Hülür, Serhat Toker, İbrahim Mazman, Çev), De Ki Basım Yayım Ltd. Şti.

Davis Kinsley, Moore Wilbert E. (1945). "Some Principles of Stratification”, American Sociological Review, Volume 10, No 2: 242-249.

Durkheim, Emile (2006.) “Toplumsal İşbölümü”, (Orijinal Yayın Tarihi 1893; Özer Ozankaya, Çev). Cem Yayınevi.

George Ritzer (2008). Auguste Comte, In The Blackwell Companion to Major Classical Social Theorists (pp27-55). Hoboken, NJ: Wiley-Blackwell.

Goldhorpe, Jhon H., ve Keith Hope (1974). "The Social Grading in Occupations: A New Approach and Scale”. Oxford: Clarendon Press.

Grabb G. Edward (1984). "Theories of Social Inequality an Introduction”, Holt, Rinehart and Winston of Canada, Limited.

Grusky, D. B.\& Galescu, Gabriela (2014). "Is Durkheim a Class Analyst”, http://web.stanford.edu/group/scspi/grusky/article files/durkheim_class_analyst.pdf

Kongar, Emre (1985). “Toplumsal Değişme Kuramlarl ve Türkiye Gerçeği”, Dördüncü Basım, Remzi Kitapevi, İstanbul.

Kösemihal, Nurettin Şazi (1968). ” Sosyoloji Tarihi” (Gözden Geçirilmiş İkinci Bask1) Remzi Kitapevi.

Kösemihal, Nurettin Şazi (1993). "Durkheim Sosyolojisi”, Remzi Kitabevi. İstanbul.

Manza, Jeff ve Brooks, Clem (1998). "Social Cleavages and Political Change”, Oxford: Oxford University Press.

Mills, Wright (1974). "Iiktidar Seçkinleri”, Bilgi Yayınevi, Ankara

(Modern Theories of Social Stratification, Erişim Tarihi, 2014, http://homepage.ntu.edu. tw/ khsu/mobile/ch5c.pdf

Morrison, Ken (2006). "Marx, Durkheim, Weber: Formation of Social Thought", Sage Publication.

Parsons, Talcott (2005). "The Social System”, Published in the Taylor and Francis e- Library. http://home.ku.edu.tr/ mbaker/CSHS503/TalcottParsonsSocialSystem.pdf

Parsons, Talcott (1961). “The Structure of Social Action”, New York: Free Press.

Parsons, Talcott (1940). "An Analytical Approach to the Theory of Social Stratification", American Journal of Sociology, Volume 45, Issue 6: 841-862.

Ritzer, George (1992). “Sociological Theory”, (Ümit Tatlıcan, Çev) McGraw-Hill, Third Edition.

http://www.umittatlican.com/files/Emile\%20Durkheim\%20(Ritzer,\%201992).pdf

Ritzer, George (2011). “Modern Sosyoloji Kuramları” (Himmet Hülür, Çev), De Ki Basım Yayım Ltd. Şti. 
Swingewood, Alan (1998). "Sosyolojik Düşüncenin Kısa Tarihi”, (Osman Akınhay, Çev.), Bilim ve Sanat Yayınları.

Tumin, Melvin M. 1953. "Some Principles of Stratification: A Critical Analysis." American Sociological Review, 18(4):387-393.

Turner, Bryan S. (2007). "Eşitlik”, (Bahadır Sina Şener, Çev), Dost Kitabevi.

Wallace, Ruth ve Wolfe, Alison (2012). "Çăgdaş Sosyoloji Kuramları: Klasik Geleneğin Genişletilmesi”, (Çevirenler, Leyla Elburuz ve Rami Ayaz), 3. Baskı, Doğu Batı Yayınları. 